\title{
POLONICA W EIGHTEENTH CENTURY SHORT TITLE CATALOGUE: PROPOZYCJA HEURYSTYCZNA
}

\begin{abstract}
Nie znam nic bardziej pociagającego i nic przyjemniejszego niż czytanie katalogu. Katalog, który czytalem teraz [...], grzeszy co prawda zbytnią zwięzlością i nie ma tej dokładności, którą archiwiści mego pokolenia wprowadzili pierwsi do prac $z$ zakresu dyplomatyki i paleografii. Pozostawia dużo do życzenia i dużo do domysłu. I może dlatego czytając go doświadczam uczuć, które u natury bardziej imaginacyjnej niż moja zasługiwałyby na miano marzenia.
\end{abstract}

Anatol France: "Zbrodnia Sylwestra Bonnard". Thum. J. Sten, Warszawa 1959, s. 8.

Dla kogoś, kto nie chce badać dziejów bibliografii, opisy bibliograficzne moga stanowić źródło pośrednie, relacjonujące, i to o dużym na ogół stopniu wiarygodności. Źródło to przynosi informacje o faktach bibliograficznych, które same, jak to zwykle bywa, też są wielowarstwowym źródłem, tyle że już bezpośrednim, wprowadzającym nas w świat twórczości piśmienniczej, ruchu wydawniczego, rzemiosła drukarskiego itp. Dobry opis bibliograficzny daje wgląd $i \mathrm{w}$ te rejony - wgląd zapośredniczony przez intencje i umiejętności bibliografa.

Przypominamy to wszystko dla asekuracji, zamierzamy bowiem bez autopsji zbadać angielską ofertę wydawniczą w niemałym, bo stuletnim wycinku czasu. Interesować nas będzie obecność wątku polskiego w tej ofercie, popełnimy więc zapewne takie same błędy jak każdy, kto zamierza rozważać treść książek na podstawie tytułów i skappych adnotacji. Bibliografia, którą w tym celu się posłużymy, ma jednak pewne wyjątkowe zalety, które nadają być może opłacalność całemu przedsięwzięciu. Nie tylko dlatego, że jest równocześnie katalogiem (i jako katalog bez wątpienia "grzeszy zbytnią zwięzłością)), ale też i z powodu możliwości szybkiego przeszukiwania według rozmaitych kluczy. Jest to bowiem bibliografia zautomatyzowana.

Od 1990 r. Biblioteka Uniwersytetu Warszawskiego dysponuje dyskiem laserowym z bazą danych ESTC i odtwarzaczem, umożliwiającym dostęp do 166796 opisów za pośrednictwem komputera typu IBM PC ${ }^{1}$. Nie miejsce tu na kreślenie fascynujących dziejów tego pionierskiego przedsięwzięcia, jakim było stworzenie Eighteenth Century Short Title Catalogue - czyli Katalogu Skróconych Tytułów Osiemnastego Wieku ${ }^{2}$. Użytkownik - dajmy na to historyk poszukujący odpowiednich materiałów - nie musi się nimi ekscytować, ani nawet ich znać. Jest istotne, że opanowanie zestawu prostych komend umożliwia mu wgląd w ogrom angielskiej 
i anglojęzycznej produkcji wydawniczej w XVIII w. W katalogu (jest to bowiem w istocie także katalog centralny) znajdują się nawet ulotki i afisze, nie ma tam tylko samoistnych wytworów techniki innej niż druk wypukły, prepada więc obfita twórczość miedziorytnicza. Szybkość wyszukiwania daje satysfakcję z bardzo intensywnego kontaktu z rejestrowanym materiałem, nawet jeśli tytuły są rzeczywiście znacznie skracane, a adnotacje o poszczególnych egzemplarzach niekonsekwentne i z rzadka stosowane.

ESTC nie jest bazą wyposażoną w indeks przedmiotowy. Interfejsy, jakimi dysponuje BUW, umożliwiają natomiast wyszukiwanie dowolnego zestawu znaków w obrębie całego opisu. W ślad za tymi, którzy badali możliwość prowadzenia wyszukiwań przedmiotowych za pośrednictwem slów kluczowych w tytułach dziel ${ }^{3}$, spróbujmy dowiedzieć się, jaki obraz Polski dotarł do angielskiego mola książkowego, pogrążonego $w$ lekturze dzieł wydanych w latach 1701-1800. Będzie to raczej gra symulacyjna niż prawdziwy „zwiad łowczy" historyka ${ }^{4}$, albowiem trudno sobie wyobrazić kompetentnego osiemnastowiecznego czytelnika, do którego nigdy nie docierały gazety - zwłaszcza w Londynie czy Edynburgu. Historyk, który zasiada do katalogu bez większej wiedzy pozaźródłowej, nieskory do pójścia za kilkoma bardziej wyrazistymi tropami, lecz zdecydowany eksploatować do dna swój katalog, też nie stanowi zbyt prawdopodobnej postaci. Ukazane przez nas strategie wyszukiwawcze moga jednak zachęcić faktycznego historyka do posłużenia się tym wciąż jeszcze unikalnym źródłem informacji.

Załóżmy, że pogodziliśmy się z osobliwościami opisu w bibliografii zautomatyzowanej, specyfiką angloamerykańskiej normy opisu bibliograficznego, a także z wadami ESTC, które postaramy się omówić w innym miejscu ${ }^{5}$. Najprostszym punktem wyjścia będzie wprowadzenie słowa poland jako wyszukiwanego zestawu znaków. System informuje nas, że znajduje się ono w opisach 80 dokumentów. Bez względu na to, jak oceniamy ten rezultat, możemy poszerzyć nasze zapytanie. Wprowadzamy jeszcze dwa zestawy: polon\$ i polish, łącząc je ze sobą i z poland spójnikiem or (lub/i), pełniącym rolę tzw. operatora logicznego. W zestawie polon\$ znak \$ (tzw. maskowanie) oznacza mniej więcej to samo, co „dowolna końcówka” - sam system podsuwa tu cztery słowa: polonais (1 dokument), poloniae (1 dokument), polonico (1 dokument), i polonois (4 dokumenty). W ten sposób liczba dokumentów, które powinniśmy przejrzeć, wzrasta do 109: są to opisy, w których znajduje się co najmniej jeden z wymienionych zestawów.

Następnie wprowadzimy jeszcze jeden zestaw: pologne. Okazuje się, że w bazie danych znajdują się 22 dokumenty z tym słowem. Po przejrzeniu ich dowiemy się, że 6 z nich zdołaliśmy już przywołać poprzednimi hasłami, 16 zaś jest nowych. Dowiemy się także, że kilka dokumentów wyszukaliśmy tylko dlatego, że w strefie adresu wydawniczego znalazła się ulica Poland Street, przy której mieścił się warsztat drukarski. Gdybyśmy znali ten fakt zawczasu, moglibyśmy wykluczyć te dokumenty operatorem logicznym (and not poland adj street). Moglibyśmy także prowadzić poszukiwania np. za pośrednictwem interfejsu OPAC, który umożliwia wybieranie zestawu znaków tylko ze strefy tytułu: w odpowiedzi na hasło poland podsuwa on nie 80, lecz 75 dokumentów. Decydujemy się jednak na pozostanie 
przy interfejsie Searchmate ze względu na zastosowany w nim dogodny sposób prezentowania opisów.

Dobór słów, które „zadajemy” systemowi jako zestawy znaków do wyszukiwania, zależy od naszej wiedzy pozaźródłowej i wyobraźni. Jak w każdym badaniu historycznym, układamy sobie pewien kwestionariusz pytań, który przybiera tutaj postać swoistego tezaurusa. Znajdą się w nim np. hasła geograficzne. Aby stały się czytelne dla systemu, musimy posłużyć się pisownią osiemnastowiecznych kart tytułowych. Trzeba ja zrekonstruować w oparciu o dostępne materiały. Dość dogodnym środkiem do tego celu wydawały się nam osiemnastowieczne encyklopedie. Niestety, "Cyclopaedia" Chambersa to, zgodnie z potwierdzoną tytułem osiemnastowieczną strukturą wiedzy, „słownik sztuk i nauk”; na próżno szukalibyśmy w nim haseł geograficznych lub biograficznych ${ }^{6}$. Krótkie hasła geograficzne zawiera natomiast „Encyclopaedia Britannica" ${ }^{7}$. Wyeliminowawszy hasla: Livonia, Courland i Pomerania, ponieważ kraje te przez większą część lub cały XVIII w. nie należały do Polski, znaleźliśmy w tej encyklopedii wiele innych, odpowiednich dla naszego zamierzenia. Choć odtworzenie zbiorowej „świadomości geograficznej” w osiemnastowiecznej Anglii wymagaloby co najmniej przejzenia hasło po haśle całej „Encyclopaedii", możemy uznać, że pochwyciliśmy większość tropów, odnajdując takie hasła, jak: Warsaw, Cracow, Posen, Dantzick, Lemburg, Poloczk, Thorn, Mazovia, Lithuania, Volhinia itp. Niektóre z nich zresztą w ogóle nie występowały w ESTC (Lemburg, Mazovia).

Chwilę nadziei przeżywamy dowiadując się, że w aż 139 dokumentach użyte jest słowo thorn, którym zastąpiliśmy - poradziwszy się Britanniki - polski „Toruń”. Okazuje się jednak, że chodzi na ogół o drukarza londyńskiego o takim nazwisku, o miejscowość w Anglii i o rzeczownik pospolity. O Toruniu mowa jest w 11 dokumentach, które bez wyjątku dotyczą głośnej sprawy ścięcia dziesięciu mieszczan za bierność wobec sprawców napaści na kolegium jezuickie (1725 r.). Przejrzenie tytułów 139 dokumentów, w których opisach zostało użyte słowo „thorn”, i wyłonienie z nich tej mniejszości, w której rzeczywiście chodziło o - jak czytamy w jednej z adnotacji - „Tarun [sic!] in Poland", zabrało nam ok. 20 min. Choć więc zwieńczenie skądinąd zautomatyzowanej procedury przynosi pewne spowolnienie pracy, nie zagraża ono wykonalności naszego przedsięwzięcia. Rozważając ten przypadek możemy nawet dojść do paradoksalnego wniosku, że proste „przeglądanie kart kartoteki” staje się w systemie zautomatyzowanym czynnością tak mało uciażliwą, iż godzimy się na nie, miast szukać dróg obejścia trudności. Jedną z takich dróg mogłoby być przeszukiwanie wyłącznie strefy tytułu, inną - takie posłużenie się operatorami logicznymi, by zestaw thorn wystąpł w kontekście eliminującym przynajmniej część przypadkowych, niepotrzebnych odpowiedzi.

Nasz kwestionariusz możemy także poszerzyć o nazwiska. Tu również pojawia się problem utworzenia odpowiedniej listy, zgodnej z domniemanym indeksem systemu. Tu także czekają nas rozczarowania: większość wybitnych pisarzy polskiego Oświecenia nie doczekała się w XVIII w. przekładów na angielski. Możemy natomiast skorzystać z faktu, że duża część nazwisk polskich miała typowe końcówki, i wyselekcjonować takie nazwiska, stosując maskowanie z lewej strony 
wyrazu (\$ski). Problem skomplikował się nieco, kiedy okazało się, że nie możemy poprosić systemu, „żeby niczego nie było z prawej”. Otrzymaliśmy zatem takie nazwiska, jak Erskine, a nawet Skinner, co już stanowi ewidentny błąd bazy danych, ujawniający jej wstępny, eksperymentalny charakter. W sumie uzyskaliśmy 43 dokumenty, z czego 28 spełniało nasze oczekiwania: zawierały one autentyczne lub literackie nazwiska polskie. Poszukiwanie zestawu \$sky zaowocowało 41 dokumentami, z których relewantnych („trafionych') było 14, a wśród pozostałych przeważały rossica, bohemica i nazwy angielskie. Na hasło \$skie otrzymaliśmy trzy odpowiedzi, w tym jedną "na temat" - było to nazwisko „Sobieskie". Wyszukaliśmy też dokument zawierający nazwisko kończące się na „cki” oraz 18 dokumentów ze słowem zawierającym rdzeń „Stanis|". Nic nie dały poszukiwania słów zawierających końcówki „-wicz" i „-vicz".

Bez zastosowania tej techniki nie dotarlibyśmy zapewne nigdy do dokumentu zawierającego nazwisko Pułaski, bowiem zastosowano w nim pisownię „Pulauski”. Uszłoby też naszej uwadze trzecie angielskie wydanie "De optimo senatore" Wawrzyńca Goślickiego ${ }^{8}$, ponieważ według karty tytułowej autor nazywał się Grimald Gozliski, a według umieszczonej w opisie wersji z autorytatywnego zbioru haseł autorskich - Grimaldus Goslicius, Laurentius, Bishop of Posen.

Opisane powyżej trudności w dobieraniu właściwej pisowni wyszukiwanego zestawu znaków można próbować przezwyciężyć posługując się opcją „rozszerzenia" (expansion on...). Korzystając z niej, przeglądamy fragment słownika, w którym znajdowałby się poszukiwany zestaw znaków, gdyby znajdował się w słowniku. W ten sposób system podsuwa nam słowa najbliższe poszukiwanemu w sensie kolejności liter - jedno z nich może okazać się tym, na którym nam w istocie zależało. Nie zwalnia to nas od pamiętania, że $w$ istocie nie dysponujemy żadną postacią indeksu rzeczowego. Poucza o tym nieudała próba uzyskania odzewu na hasło plica polonica. A przecież fenomen kołtuna był dobrze znany w całej ówczesnej Europie; sporo miejsca poświęcono mu np. w „Cyclopaedii” Chambersa (London 1791). Tyle tylko, że autor nie dysponował żadną monografią kołtuna: powołuje się na lacińskie dzieło, dotyczące chorób występujących w pewnych królestwach. Choćby cała uczona Anglia kupowała tę książkę wyłącznie w celu czytania o kołtunie, ESTC będzie o tym milczeć; milczenie to nie zostanie przerwane nawet wtedy, gdyby pracę tę, zapewne opublikowaną w Niemczech, wydano po angiel$\mathrm{sku}^{9}$. Nie jest też ESTC dobrym przewodnikiem po literature o niejasnych, ogólnikowych tytułach, chyba że się zna typowe sformułowania używane przez komentatorów politycznych lub tytuły gazet, z których przedrukowywano artykuły ${ }^{10}$.

W sumie za odpowiadające celom naszego poszukiwania uznaliśmy 152 pozycje. Każde nowe wydanie liczyliśmy jako odrębną pozycję. Po bardziej wnikliwym badaniu można by zapewne osiągnąć 200 pozycji, a nowa wersja bazy danych ESTC, która miała znaleźć się na rynku w styczniu 1992 r., demonstrowana przez Michaela Crumpa w czasie Szkoły Jesiennej nt. Humanista przy Komputerze zorganizowanej w Karpaczu w dn. 12-15 XII 1991 r., jako dwukrotnie obszerniejsza może takich poloniców zawierać i czterysta.

Ze zgromadzonego materiału wyłania się obraz dość wyrazistej obecności Polski w piśmiennictwie brytyjskim w XVIII w., zwłaszcza w latach 1716-1741 (54 
poz.) i 1772-1800 (71 poz.). Jest to wszakże obecność zapośredniczona w dużym stopniu przez rynek książki francuskiej i niemieckiej. 72 pozycje, tj. $47,4 \%$ calego tego dorobku to prace, o których można powiedzieć, że mają Polskę za swój przedmiot, że jej bezpośrednio dotyczą.

Przyjrzyjmy się strukturze tematycznej zgromadzonego piśmiennictwa. Podzieliliśmy je arbitralnie na grupy o różnym zakresie; ustawmy je zatem według liczebności.

I (21 poz.) - bieżąca ogólna literatura polityczna.

II (17 poz.) - prace historyczno-geograficzne i relacje z podróży, niekoniecznie poświęcone wyłącznie Polsce.

III (po 15 poz.) - publicystyka poświęcona rozbiorom, Sejmowi Czteroletniemu i Konstytucji 3 Maja; piśmiennictwo w sprawie kwestii dysydenckiej w Polsce.

IV (13 poz.) - publikacje, w których sprawy Polski omawiane są na marginesie głównego nurtu rozważań lub przywołane w formie przypadkowej wzmianki.

V (11 poz.) - historie Polski i opisy podróży po Polsce.

VI (po 10 poz.) - prace Polaków: Tadeusza Krusińskiego, Stanisława Leszczyńskiego, Stanisława Poniatowskiego, Michała Wielhorskiego i Hieronima Zahorowskiego (który w ESTC jest znany wyłącznie jako Jerome Zaorowsky), w tym liczne edycje nieznane Estreicherowi. Na tym samym miejscu znajduje się też grupa prac beletrystycznych, co do których uzasadnione wydawałyby się podejrzenia, że pojawiają się w nich wątki lub symbole polskie.

VII (9 poz.) - judaica.

VIII (8 poz.) - pisma Maurycego Beniowskiego lub o Beniowskim.

IX (po 7 poz.) - relacje o osobach królów Polski lub opisy ich dworów; pamiętniki słynnego karła Józefa Borusławskiego i afisze zapowiadające jego występy.

X (5 poz.) - pisma poświęcone Klementynie Sobieskiej.

XI (1 poz.) - nieznana Estreicherowi publikacja amerykańska, w której znajduje się wzmianka o Kazimierzu Pułaskim ${ }^{11}$.

W odniesieniu do trzech prac jesteśmy bezradni: nie potrafimy na podstawie opisów bibliograficznych zakwalifikować ich do żadnej z grup.

Całościowy i rozległy obraz pewnego zjawiska, wstępnie naszkicowany przy pomocy takiej bazy, może też prowadzić do odkrycia interesujących szczegółów i zainicjować rozważania najzupełniej mikrograficzne. W przypadku naszego przedsięwzięcia jest to przede wszystkim wykrycie druków nieznanych Estreicherowi i Katalogowi Centralnemu Starych Druków w Bibliotece Narodowej ${ }^{12}$.

Interesujące są też sytuacje, w których Estreicher zdaje się wiedzieć więcej, a w każdym razie - co innego, niż dzisiejsi bibliografowie brytyjscy. Sytuacja taka występuje w przypadku książki niejakiego Lindsey'a „Les droits des trois puissances allies sur pluisierus provinces de la republique de Pologne" (Londres 1774). Według adnotacji ESTC, jest to przekład $z$ angielskiego, dokonany przez J.M. Gerarda de Rayneval, a wydany w rzeczywistości w Gdańsku, co już samo jest szczegółem godnym badań. Estreicher $(X X \mid, 289)$ podaje: Lindsey Teofil, unitariusz (1753-1808), posługujący się pseudonimem Pansmouzer. Wymienia też inną francuskojęzyczną pracę Lindsey'a: „Le partage de la Pologne en sept dialogues" 
(Londres: Elmsly, b.r.). Polskie biblioteki (np. Czartoryskich i Kórnicka) mają wiele egzemplarzy tej książi: w ich kartach w Katalogu Centralnym jako autor pojawia się Lindsey lub Pansmouser. ESTC w wersji z 1987 r. nie znało tej pozycji; dzięki współpracy koordynowanej przez BUW luka ta zostanie wypełniona. W ESTC znajdujemy natomiast: Pansmouzer Gotlieb („a pseudonym”; nb. pisownia imienia przez jedno $t$ jest zapewne pomyłką wprowadzającego dane, tym bardziej, że w adnotacji czytamy z kolei Gotleib): „The Polish partition, illustrated, in seven dramatic dialogues" (London: Elmsly [1773]). Estreicher (XXI, 290) przypisuje ponadto Lindsey'owi, ujawniając jednak swoje źródła i wątpliwości, dziełko „Refutation litteraire et politique de l'ouvrage dialogue ayant pour titre Le partage de la Pologne" (Cantorbery [sic!] 1725), które ESTC rejestruje jako pracę anonimową, opublikowaną prawdopodobnie w Niderlandach.

Bibliografia uzyskana przy pomocy ESTC jest - jak każda bibliografia źródłem jednostronnym i surowym. Wydaje się jednak, że po odpowiedniej obróbce mogłaby dostarczyć cennego materiału, a cenność ta wynikałaby z dwóch czynników. Pierwszym jest maksymalizacja szansy uzyskania istotnych informacji. W tradycyjnym wyszukiwaniu bibliograficznym, skupiając się na precyzji jednostkowych danych, musimy stracić z oczu całość zarejestrowanego materiału; nie sposób go już w każdym razie traktować jako swoistego źródła zbiorowego, co właśnie próbowaliśmy zrobić z opisami ESTC. Innymi słowy, poszukując źródeł historycznych w bibliografiach drukowanych i rękopiśmiennych, na kartach katalogów i kartotek, tylko z największym trudem drążymy je „wgłąb" i równocześnie „wszerz”. Drugi czynnik - jest to łatwość uzyskiwania informacji. Dostępność bazy danych w trybie on-line lub na „kompakcie” (co na jedno wychodzi), znacznie poprawia ekonomikę poszukiwania historycznego. Tym samym może zresztą prowadzić do zarzucenia badacza informacjami, których ten nie będzie w stanie uporządkować, dopóki nie poprawi „ekonomiczności” swojego myślenia. O ile jednak samo myślenie nie może być na razie wsparte przez komputery, historyk ma do dyspozycji programy, umożliwiające mu tworzenie własnych, „warsztatowych" baz danych i czerpanie z nich wszelkich korzyści. Jest to jednakże już zupełnie odrębna kwestia.

\section{Przypisy}

${ }^{1}$ A. Sitarska, Bazy danych o starych drukach, problemy tworzenia i organizacji pracy, $\left.\mathrm{W}:\right]$ Z teorii $i$ praktyki księgoznawczej (Acta Universitatis Lodziensis, Folia Librorum 2), Łódź 1991, s. 221-233.

${ }^{2}$ R.C. Alston, M.J. Janetta, Bibliography, machine readable cataloguing and the ESTC. A summary history of the Eighteenth Century Short Title Catalogue, London 1978.

${ }^{3}$ Por. Searching the Eighteenth Century. Papers presented at the Symposium on the Eighteenth Century Short Title Catalogue in July 1982, red., M. Crump, M. Harris, London 1983.

${ }^{4}$ Metafora użyta przez prof. Barbarę Bieńkowską.

${ }^{5}$ W materialach Szkoły Jesiennej nt. Humanista Przy Komputerze, Karpacz, 12-15 XII 1991, gdzie wstępna wersja prezentowanego tutaj tekstu zostala wygłoszona w formie komunikatu.

${ }^{6}$ E. Chambers, Cyclopaedia, or, an universal dictionary of arts and sciences..., wyd. 6, London 1750; Cyclopaedia, or, an universal dictionary of arts and sciences... with the supplement, and modern improvements..., London 1791. 
${ }^{7}$ Encyclopaedia Britannica or, a dictionary of arts and sciences, compiled upon a new plan, London 1773.

${ }^{8}$ Por. F. Filipowicz, Goślickiego De optimo senatore a myśl polityczna w krajach anglosaskich, „Przegląd Współczesny", 1934, R. 13, s. 68-79.

${ }^{9}$ Nie rozwiazywaliśmy danych bibliograficznych, podanych przez Chambersa: Hoffman. De morb. cert. Reg. propr.

${ }^{10} \mathrm{~Np}$. Alfred's letter of a review of the political state of Europe to the end of the summer 1792..., London 1793. - Rzecz dotyczy Polski, por. Z. Libiszowska, Zycie polskie w Londynie w XVIII w., Warszawa 1972, s. 286.

11 J.-B. Louvet de Couvray, Love and patriotism! or, the extraordinary adventures of M. Duportail... Interspersed with many surprising incidents on the life of the late Count Pulauski, Philadelphia 1797.

${ }^{12} \mathrm{~Np}$. Lettres sur la negociation de laffaire de Malthe en Pologne. Ecrits par un habitant de Varsovie a son ami a Londres, Londres (i.e. Warsaw?) 1775; T. Hawers: The three Kings: containing incidents singularly amusing, as well as strikingly providential, in the lives of Gustavus Vasa, King of Sweden; Charles II. King of England; Stanislaus II. King of Poland..., London 1796; P.F. Guyot Desfontaines: The history of the revolutions of Poland, from the foundation of that monarchy, to the death of Augustus II... Translated from the original French, London 1736. (Pisownia według opisów ESTC.) 